\title{
Effects of additional caged and free-running queens on honey bee (Apis mellifera) colony performance
}

\author{
BP Oldroyd ${ }^{1 *}$, PJ Hunt 2 \\ 1 USDA, Agricultural Research Service, Honey-Bee Breeding, \\ Genetics and Physiology Laboratory, 1157 Ben Hur Road, Baton Rouge, LA 70820, USA; \\ 2 Plant Research Institute, Department of Agriculture and Rural Affairs, \\ Burnley Gardens, Swan Street, Richmond 3121, Australia
}

(Received 1 November 1989; accepted 3 August 1990)

\begin{abstract}
Summary - Colonies were established containing the following combinations of queens : 1 freerunning queen, 2 free-running queens, 1 free-running queen and 1 caged queen, and 1 free-running queen and 4 caged queens. Brood area and colony weight gain were measured for each treatment. Colonies with 1 queen had the highest colony weight gain. The presence of additional queens in colonies had several negative effects on performance. Mortality of free-running queens was increased by the presence of 1 caged queen, which caused a reduction in brood area and colony weight gain. There was no significant difference in the brood production of single queen colonies, and colonies containing 2 free-running queens. The results do not support the use of caged queens or 2-queen colonies for increasing honey production.
\end{abstract}

Apis mellifera / multi-queen system / honey production / colony performance

\section{INTRODUCTION}

Under certain environmental conditions, honey bee colonies containing 2 laying queens have more bees and produce more honey than colonies containing a single queen (eg Moeller, 1976). There are 2 likely explanations for the positive effects of additional queens. First, 2 queens should have the capacity to produce more eggs than a single queen, and should therefore be able to develop populous colonies more rapidly. Depending on the environment, populous colonies usually produce more honey than colonies with smaller populations (Farrar, 1937). Second, 2 queens should produce greater amounts of queen pheromones than a single queen.
It has been shown that decreasing the amount of queen pheromones in a colony has a number of depressive effects on workers (Free, 1987). Colonies deprived of queen pheromones raise less brood (Free and Racey, 1968), build less comb (Darchen, 1957, 1968), have decreased foraging rates (Free, 1967; Jaycox, 1970; Free et al, 1985), and have decreased colony weight gain and worker longevity (Delaplane and Harbo, 1987) relative to normal colonies. Free (1987) has postulated that the presence of queen pheromones stimulates all these activities, and proposed that arranging to have higher than normal levels of queen pheromones in honey bee colonies might stimulate higher rates of worker activity and colony productivity. Youngs and Burgett (1982) demon-

\footnotetext{
* Correspondence and reprints
} 
strated that synthetic 9-oxodec-trans-2enoic acid, a major queen pheromone, stimulated pollen foraging in queenless bees, although the bees did not approach the foraging rates of queenright colonies.

The present experiment was designed to determine whether 2-queen colonies are superior honey producers to single queen colonies because 2 queens produce more eggs or because they produce more pheromones. If pheromones are the sole cause of improved productivity in 2queen colonies, then there may be several important consequences:

- a second caged queen might be able to improve honey yield just as well as a second free-running queen; if this is the case, then the management of 2-queen systems could be greatly simplified;

- if the responsible pheromone(s) can be identified, then it might be possible to synthesize it or them, and provide colonies with an artificial source in order to stimulate production;

- if queen pheromones are important components of queen phenotypic merit, then this should be taken into account in designing honey bee breeding programs (Chevalet and Cornuet, 1982; Oldroyd and Goodman, 1990). The amount of pheromone produced has been shown to be highly heritable for at least 1 pheromone (Moritz and Hillesheim, 1985).

\section{MATERIALS AND METHODS}

On 6 December 1988, in Southern Victoria, Australia, 20 8-frame Langstroth colonies were standardized so that each had 4 and 5 frames of brood in the top and bottom hive bodies respectively, and so that each had approximately uniform adult population sizes and food reserves.

The following 4 treatments were then randomly allocated to these colonies, with 5 colonies per treatment :
- 1 free-running queen having access to 2 brood chambers;

-2 free-running queens, with each queen having access to a single brood chamber and separated by a double queen excluder;

- 1 free-running queen having access to 2 brood chambers, and another queen caged;

- multi-queen colonies with 1 free-running queen having access to 2 brood chambers, and 4 caged queens.

Figure 1 shows the arrangement of the colonies for each treatment. Figure 2 shows the design of the cages used for the confined queens.
A

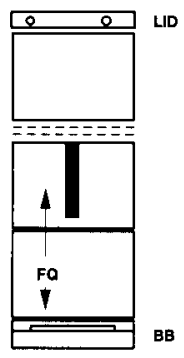

C

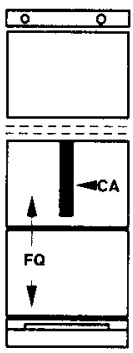

B

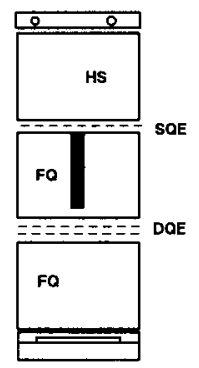

D

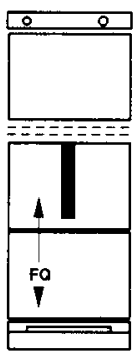

Fig 1. Arrangements of colonies used to assess the affects of multiple queen bees on honey and brood production. HS : honey super; SQE : single queen excluder; DQE : double queen excluder; $F Q$ : free-running queen; $C A$ : cage (see fig 2). A. Treatment 1 (control): a free-running queen with access to 2 brood chambers. No queens in the cage block. B. Treatment 2: two free-running queens separated by a double queen excluder. No queens in the cage block. C. Treatment 3: a free-running queen with access to 2 brood chambers. One caged queen in the cage block. $D$. Treatment 4: a free-running queen with access to 2 brood chambers. Four caged queens in the cage block. 


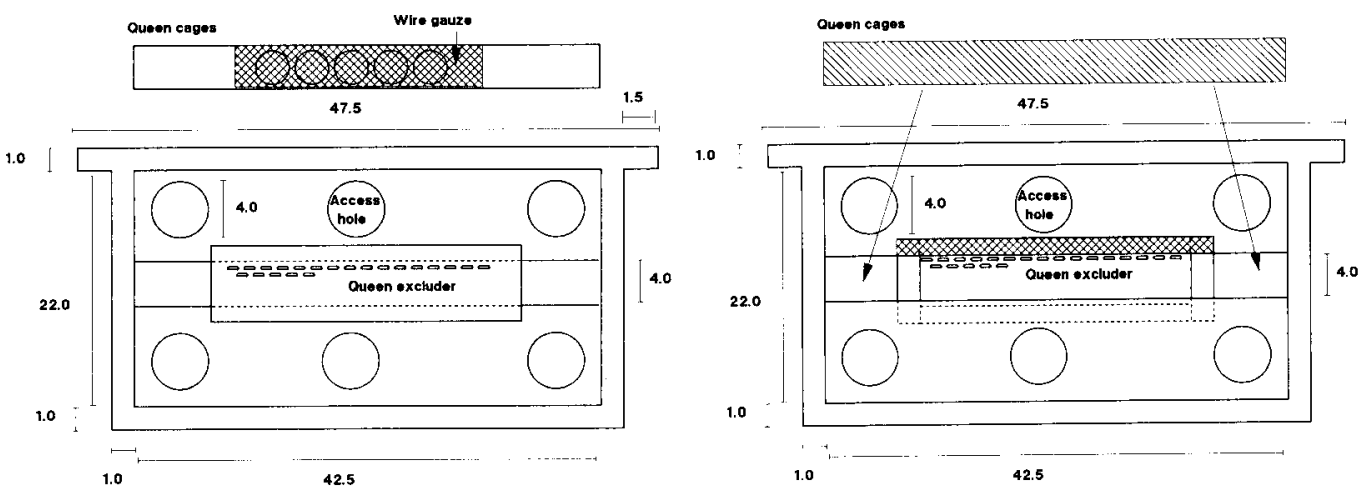

Fig 2. Holder for the queen cages. All measurements are in $\mathrm{cm}$. A. Front projection: the queen excluder prevented the free-running queen from directly contacting the caged queen or queens. Workers could pass freely through the queen excluder, and contact the queen inside. B. Rear projection: the queen cages fitted in the back of the queen cage holder.

These cages allowed close physical contact between workers and queens, but a strip of queen excluder prevented free-running queens from contacting confined queens. All the queens used were young, open-mated sisters, derived from a single queen mother that had been mated to brother drones from the same highly inbred $A m$ ligustica line.

The colonies were moved to 4 separate sites during the course of the experiment. Table 1 gives the locations of the sites, the dates the colonies were at each site, and the predominant nectar source at that site. This sequence of migration was typical of commercial beekeeping practice in Victoria during the 1988-1989 sea- son. The colonies were weighed at the commencement and end of the experiment, and when they were moved to each new site using a clock faced scale accurate to $\pm 0.5 \mathrm{~kg}$. Approximately fortnightly, the brood areas of each colony were measured by placing a $5 \times 5 \mathrm{~cm}$ wire grid over each brood comb, and counting the number of squares that covered brood (eggs, larvae and pupae, both worker and drone).

As soon as more than $50 \%$ of a comb of honey was capped, it was removed from the colony and replaced with an empty comb. This ensured that the colonies always had sufficient room for honey storage and brood rearing. The weight of honey removed was determined by re-

Table I. Dates, locations, and major species worked by the colonies. All sites were in Southern Victoria, Australia.

Dates

Predominant nectar

Locality source

12 Dec 1988-13 Jan 1989

13 Jan-17 Feb 1989

17 Feb-9 March 1989

9-30 March 1989
Trifolium repens

Knoxfield

Trifolium repens

Encalyptus macrorhyncha

Eucalyptus microcarpa
Ellinbank

Avoca

Castlemaine 
weighing the colony. This weight was added to the gross weight gain for the colony at the site. In this way we were able to determine total colony weight gains for each site.

At each inspection, any queens that had died were replaced by queens available from nuclei maintained near the experimental colonies. Thus, all colonies were restored to their intended configuration of queens within $7 \mathrm{~d}$ of any queen dying. To increase the rate of acceptance of new queens, in those colonies with caged queens, we released a caged queen and introduced a new queen to the cage block.

\section{RESULTS}

\section{Brood area}

The mean brood areas for each treatment are plotted in figure 3. A repeated measures analysis of variance (Milliken and Johnson, 1984) was used to assess any differences between treatments (table II). Overall, brood production was significantly $(P<0.01,2$-tailed $t$-test) lower in the treatment 3 colonies (which had 1 caged queen) relative to the treatments with 4 caged queens, and those with 2 freerunning queens. This reduction was probably due to the high number of deaths of free-running queens in treatment 3 (fig 4). This treatment had particularly small amounts of brood during the summer period (d 0-90, fig 3). Colonies with 2 freerunning queens did not differ significantly in brood area from the control colonies.

\section{Weight gain}

Figure 4 gives the mean colony weight gain for each treatment group at each site. A repeated measures analysis of variance (Milliken and Johnson, 1984) was used to assess differences between treatments (table II). Control colonies with a single free-running queen had the highest weight gains at all sites, though the differences were not all significant. However overall, control colonies had a significantly higher weight gain than all other treatments $(P<$ 0.05 , 2-tailed $t$-test). At the Ellinbank and

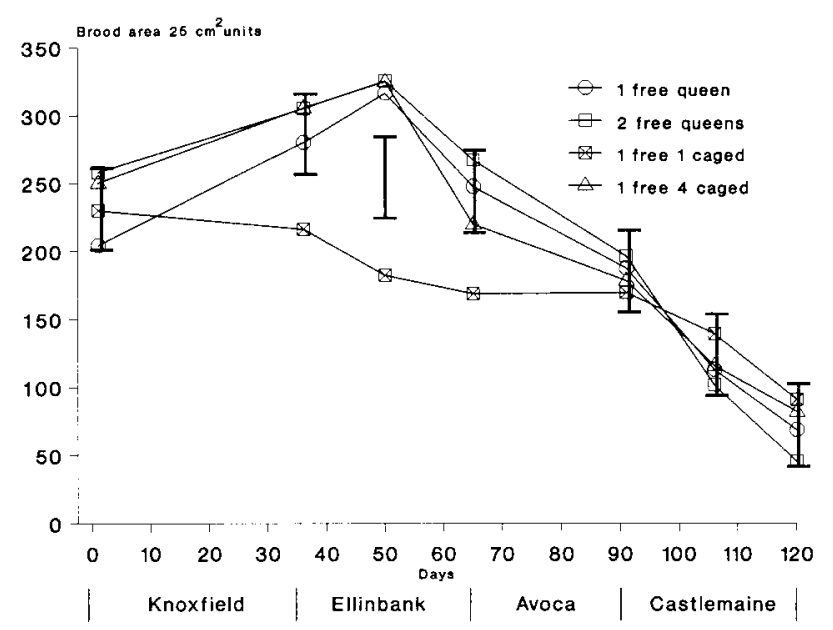

Fig 3. Mean brood area, in $25 \mathrm{~cm}^{2}$ units, for colonies in each of the 4 treatment groups. $D 0=6 \mathrm{De}-$ cember 1989 . The bars indicate the $5 \%$ Isd for that measurement. 
Table II. Repeated measures analysis of variance of brood area (25 $\mathrm{cm}^{2}$ units) and colony weight $(\mathrm{kg})$ gain of colonies containing caged and free-running queens.

\begin{tabular}{lrrrr}
\hline Source & $d f$ & Mean square & $F$ & $P$ \\
\hline Brood area & & & & \\
Treatment $(T r)$ & 3 & 13599.8 & 4.1 & 0.02 \\
Error & 16 & 3350.9 & & \\
Time (Ti) & 6 & 129865.6 & 60.6 & 0.0001 \\
Trx Ti & 18 & 5940.3 & 2.8 & 0.0007 \\
Error & 96 & 2144.6 & & \\
Weight gain & & & & \\
Treatment $(\mathrm{T})$ & 3 & 148.7 & 4.2 & 0.02 \\
Error & 16 & 35.2 & & \\
Honey flow $(\mathrm{H})$ & 3 & 2000.7 & 105.7 & 0.0001 \\
HxT & 9 & 24.6 & 1.3 & 0.3 \\
Error & 48 & 18.9 & & \\
& & & & \\
\hline
\end{tabular}

Avoca sites, the treatment with a single caged queen and 1 free-running queen had significantly reduced colony weight gain compared with the control colonies. The treatment with 4 caged queens had significantly reduced weight gains at Avoca, compared with the controls, but was not significantly different at the other sites.

\section{Queen mortality}

During the course of this experiment a number of queens died, which may have influenced the results obtained. In figure 4, we present the number of free-running queens which were recorded as dead at each site. Colonies with 1 caged queen

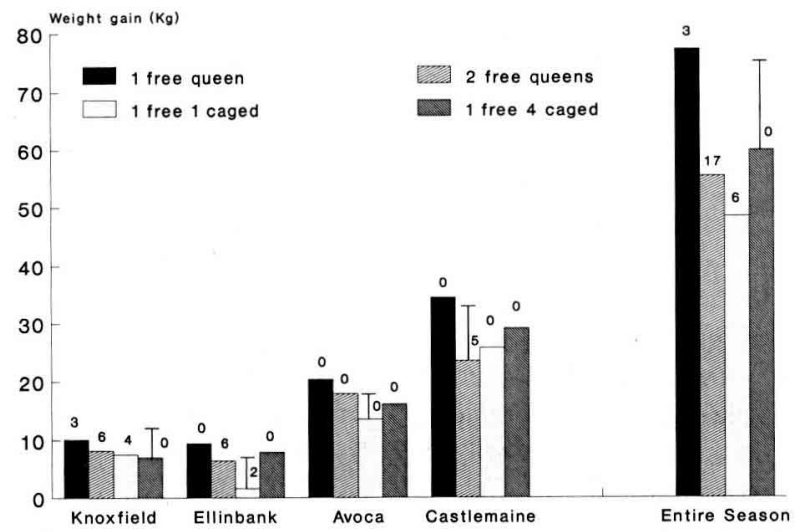

Fig 4. Mean colony weight gain $(\mathrm{kg})$ for colonies in each of the 4 treatment groups at 4 separate sites to which they were trucked. The bars indicate the $5 \%$ Isd for that site, and the numbers indicate the number of free-running queens which died at that site in that treatment. 
had a high number of queen deaths at Knoxfield and Ellinbank. During the summer dearth at Ellinbank, and during the very heavy nectar flow at Castlemaine, a number of queens were lost in the treatment with 2 free-running queens. However, none of these colonies had both queens lost at the same time. There was no evidence that moving the colonies caused an increase in queen mortality.

\section{DISCUSSION}

The hypothesis that increased egg-laying capacity of 2 queens leads to the often reported increased honey production of 2queen colonies predicts that colonies with 2 free-running queens would have had the greatest brood areas and weight gains. The alternative hypothesis, that increased production of 2-queen colonies is due to increased queen pheromone production, would be supported if all colonies with more than 1 queen had exceeded the single-queen colonies in weight gain, provided that these pheromones are produced and transferred to the worker population as efficiently by caged queens as by free-running queens. If the stimulatory effects of queen pheromones were additive, then the colonies with 4 caged queens (treatment 4) would have been expected to have the highest production. None of these results were observed in our study.

There is no support for hypothesis 1 in the data. Colonies with 2 free-running queens did not maintain significantly larger brood nests than other treatments or the control. However, we cannot conclude from this evidence that 2-queen colonies do not contribute to production under all circumstances. This experiment was conducted from early summer (Knoxfield) to autumn (Castlemaine). Two-queen colonies may have higher rates of population increase in spring. Thus if 2-queen colonies can be established and maintained in early spring, the additional egg-laying capacity may allow more rapid build-up of colony populations. This advantage is probably lost during protracted honey-flows, such as are found in Australia. Moeller (1976) has suggested that 2-queen and single-queen colonies eventually obtain equivalent maximum population sizes. Furthermore, it is difficult to maintain 2 queens in a colony during heavy nectar flows, dearth periods, and in autumn (fig 3, see also Moeller, 1976). Thus the major conclusion of this study is that the practice of maintaining 2-queen colonies beyond spring is questioned by these data.

Our data do not support hypothesis 2 , but neither do they provide strong evidence against it. Colonies with 1 freerunning queen and 1 caged queen lost a higher proportion of free-running queens than the other treatments (fig 2). Thus the significantly reduced brood area and weight gain observed for this treatment is most likely due to this cause alone. The colonies with 4 caged queens lost no freerunning queens. However, this treatment still caused a significant reduction in weight gain at the Avoca site and overall, compared with the single-queen colonies (fig 4). Clearly, the result obtained from this treatment shows that placing caged queens in honeybee colonies in the manner described does not increase production, but rather reduces it. It is possible that the caged queens produced some pheromones whose presence was inimical to honey production, and that these were transferred to the worker population, or had an adverse effect on the free-running queen. This does not mean that all queen pheromones have a negative effect on production. Queen honey bees produce a wide array of pheromones which are transferred to the worker population in different 
ways (Free, 1987). Many pheromones are transferred by physical contact between queen and workers and are then spread around the colony by the contacting worker (Seeley, 1979). However, others are probably spread from tarsal glands as the queen walks over the comb (Lensky and Slabenzki, 1981). These kinds of pheromones may not be effectively transferred from caged queens to the worker population. Even pheromones which are normally spread by cuticular contact may not be easily transferred from caged queens. It is also possible that caged queens do not produce the same kind of pheromones as free-running queens.

We conclude that caged queens cannot be used to increase honey production using the procedures outlined here. Under our experimental and environmental conditions, caged queens had a negative effect on colonies by reducing weight gains and/ or causing increased mortality of freerunning queens. Because other researchers (eg Jaycox, 1970; Youngs and Burgett, 1982; Winston, personal communication) have shown that a single artificial queen pheromone can stimulate worker activity, further research is required to determine if any of the range of queen pheromones can be used to increase production. Our results do not eliminate the possibility of this kind of research being fruitful, as we did not determine if stimulatory pheromones were produced by the caged queens or were transferred to the worker population. Alternative methods of queen storage might also enhance the transfer and production of queen pheromones to the worker population.

\section{ACKNOWLEDGMENTS}

This research was conducted at the Plant Research Institute. We thank $R$ Goodman for assistance in all stages, and the Australian Honey
Research Council for continuing financial support. R McDonald provided apiary sites and the good oil on honey flows. Work conducted in the US was realized in cooperation with the Louisiana Agricultural Experiment Station.

\section{Résumé - Action de reines supplémen-} taires encagées et libres sur les performances de colonies d'abeilles (Apis mellifera L). Dans certaines conditions d'environnement, des colonies d'abeilles à 2 reines produisent des populations plus fortes et une plus grande quantité de miel que des colonies normales à 1 reine (Moeller, 1976). Cette amélioration peut être due à 2 causes : 2 reines peuvent produire plus d'œufs qu'une seule, ou 2 reines peuvent produire plus de phéromone royale qu'une seule et ces phéromones peuvent inciter les ouvrières à augmenter leur activité de butinage ou d'autres types de comportement impliqués dans la production. La présente expérimentation a pour but de déterminer l'importance relative de ces 2 effets.

Des colonies ont été formées avec les combinaisons de reines suivantes : une reine libre, 2 reines libres, une reine libre et une reine encagée, une reine libre et 4 reines encagées. La figure 1 montre la disposition des reines dans les colonies. La figure 2 présente les cages utilisées pour maintenir les reines encagées. Chaque traitement a été répété sur 5 colonies.

Nous avons mesuré la surface de couvain (fig 3) et le gain de poids de la colonie (fig 4) pendant une saison. Les colonies avec 2 reines libres n'ont pas entretenu un nid à couvain significativement plus grand que celles des autres traitements ou que les témoins (fig 3). Les colonies avec une reine encagée et une reine libre ont eu une surface de couvain et un gain de poids significativement réduits par rapport à tous les autres traitements (fig 3 et 4). Dans ce cas, la reine encagée semble accroître la 
mortalité de la reine libre, provoquant des effets négatifs. Quatre reines encagées ne semblent pas modifier la production de couvain ni affecter la mortalité de la reine libre. Néanmoins le gain de poids de la colonie baisse. Toutes les colonies avec reines supplémentaires ont donc une production réduite par rapport aux colonies à une seule reine.

Nous en concluons que des reines encagées ne peuvent pas être utilisées pour augmenter la production de miel dans les conditions de milieu et d'expérience présentes.

Apis mellifera / colonie polygyne / production de miel / performance de la coIonie

\section{Zusammenfassung - Einfluß zusätzli-} cher gekäfigter und freilaufender Königinnen auf die Volksleistung. Unter bestimmten Umweltverhältnissen wurde nachgewiesen, daß Bienenvölker mit zwei Königinnen größere Volksstärken und höhere Honigernten erreichen als normale Völker mit nur einer Königin (Moeller, 1976). Es gibt zwei mögliche Erklärungen für diese Steigerung : Zwei Königinnen könnten mehr Eier legen als nur eine einzelne; oder zwei Königinnen könnten mehr Königinnen-Pheromon erzeugen als eine einzelne und die Pheromone (Weiselsubstanzen) könnten die Arbeiterinnen zu höherer Trachtleistung und anderen Verhaltenseigenchaften anregen und damit die Produktion steigern. Die vorliegenden Versuche wurden durchgeführt, um die relative Bedeutung dieser beiden Effekte zu bestimmen.

Es wurden Völker mit folgender Königinnen-Kombination gebildet: Eine freilaufende Königin, zwei freilaufende Königinnen, eine freilaufende und eine gekäfigte Königin sowie eine freilaufende und vier gekäfigte Königinnen. Abb 1 zeigt die Anordnung der Königinnen in den Völkern. Auf Abb 2 sind die Käfige zur Aufnahme der gekäfigten Königinnen zu sehen. Jede Versuchsanordnung wurde mit fünf Wiederholungen durchgeführt.

Eine Saison lang wurden die Brutflächen (Abb 3) und die Gewichtszunahmen (Abb 4) gemessen. Völker mit zwei freilaufenden Königinnen unterhielten kein signifikant größeres Brutnest als die anderen Anordnungen oder die Kontrollen (Abb 3). Völker mit einer gekäfigten und einer freilaufenden Königin hatten deutlich kleinere Brutflächen und geringere Gewichtszunahmen gegenüber allen anderen Anordnungen (Abb 3 und 4). Die gekäfigte Königin shien zu einer erhöhten Mortalität bei der freilaufenden Königin zu führen, was dieses negative Ergebnis zur Folge hatte. Vier gekäfigte Königinnen schienen weder die Brutmenge noch die Mortalität der frejlaufenden Königin zu verändern; sie verminderten jedoch die Gewichtszunahme des Volkes. Es hatten also sämtliche Völker mit zusätzlichen Königinnen eine verringerte Honigproduktion im Vergleich zu Normalvölkern mit einer einzigen Königin.

Wir ziehen aus unseren Versuchen den Schluß, daß zusätzliche gekäfigte Königinnen unter diesen Umwelt- und Versuchsbedingungen nicht zur Steigerung des Honigertrages verhelfen können.

Apis mellifera / polygyne Völker / Honigproduktion / Volksleistung

\section{REFERENCES}

Chevalet C, Connuet JM (1982) Etude théorique sur la sélection du caractère «production de miel» chez l'abeille. I. Modèle génétique et statistique. Apidologie 13, 39-65

Darchen R (1957) La reine d'Apis mellifica, les ouvrieres pondeuses et les constructions cirières. Insectes Soc 4, 321-325 
Darchen $R$ (1968) Le rôle de la reine dans la construction cirière. In : Traité de biologie de l'abeille, t II (Chauvin R, éd) Masson, Paris, 305-324

Delaplane KS, Harbo JR (1987) Effect of queenlessness on worker survival, honey gain and defence behaviour in honeybees. J Apic Res $26,37-42$

Farrar CL (1937) The influence of colony populations on honey production. J Agric Res 54 , 945-954

Free JB (1967) Factors determining the collection of pollen by honeybee foragers. Anim Behav 9, 134-144

Free JB (1987) Pheromones of Social Bees. Cornell Univ Press, Ithaca, 61-65

Free JB, Racey PA (1968) The effect of the size of honeybee colonies on food consumption, brood rearing and the longevity of bees during winter. Entomol Exp Appl 11, 241-249

Free JB, Ferguson AW, Simpkins JR (1985) Influence of virgin honeybees (Apis mellifera) on queen rearing and foraging. Physiol Entomol 10, 271-274

Jaycox ER (1970) Honey bee queen pheromones and worker foraging behaviour. Ann Entomol Soc Am 63, 222-228
Lensky $Y$, Slabezki $Y$ (1981) The inhibiting effect of the queen bee (Apis mellifera $L$ ) footprint pheromone on the construction of swarming queen cups. $J$ Insect Physiol 27, 313323

Milliken GA, Johnson DE (1984) The Analysis of Messy Data. Vol 1 : Designed Experiments. Van Nostrand Rienhold, New York, 322-350

Moeller FE (1976) Two-Queen System of Honey-bee Management. USDA Prod Res, Report 161

Moritz RFA, Hillesheim E'(1985) Inheritance of dominance in honeybees (Apis mellifera capensis Esch). Behav Ecol Sociobiol 17, 8789

Oldroyd BP, Goodman RD (1990) On the relative importance of queen and worker characters to honey production. Apidologie 21, 153159

Seeley TD (1979) Queen substance dispersal by messenger workers in honeybee colonies. Bohav Ecol Sociobiol 5, 391-415

Youngs LC, Burgett M (1982) Effects of synthetic 9-oxodec-trans-2-enoic acid on the foraging activities of honey bees. Am Bee J 122, 773-775 